\title{
UNIFIED MODEL OF MULTIPLE WIND TURBINES
}

\author{
A. Mutule, O. Kochukov \\ Laboratory for Power System Mathematical Modelling, \\ Institute of Physical Energetics, \\ 21 Aizkraukles Str., Riga, LV-1006, LATVIA \\ Riga Technical University \\ 1 Kalku Str., Riga, Latvia
}

\begin{abstract}
An approach is proposed to the modelling of wind farms in the electric power system long-term planning. It allows a specialist to perform calculations based on scanty information and offers a set of ready-to-use data for easy, fast, and precise modelling. The authors exemplify the calculations of wind speed probability density and power curves and give an idea for relevant corrections. They also show how to pass from a single wind turbine model to the unified model of multiple wind turbines which would meet the requirements of long-term planning tasks. The paper presents the data on wind farms that are operating in UK and Oceania.
\end{abstract}

Keywords: wind energy, wind farm, power system planning, power system modelling.

\section{INTRUDUCTION}

Long-term planning plays a significant role in development of any power system (PS). Its objective is to determine the minimum cost strategy for long-range expansion of the generation and transmission systems that would be adequate to supply the forecasted load within a set of technical, economic and political constraints [1]. Moreover, careful planning of the power sector is of great importance, since the decisions to be taken involve commitments associated with large resources, which implies potentially serious economic risks for an electrical utility and the economy as a whole. Each element of the network is to be modelled taking into consideration all the present and future conditions of the PS, including power plant types [2]. Since there are several types of power plants, methods for their modelling also vary. The production curves might differ - some of them (e.g. for CHP and hydro power plants) are controllable or easy to predict, while others (e.g. for wind turbines) cannot be controlled or predicted. The growing share of wind farms (WFs) in the world has led to the necessity of highlighting the question of relevant modelling. The average power value of a turbine cannot be used for modelling due to very low accuracy of the final results; therefore, more complicated modelling techniques have to be applied. Furthermore, modelling the parallel operation of multiple - from tens to hundreds - wind turbines is even a more complicated task, which involves numerous factors. In particular, we should 
take into account the wind speed distribution throughout the whole farm, the geographical landscape, different times of non-availability, etc. Often for the specialist dealing with PS planning it is difficult to obtain all the parameters needed for accurate calculation; therefore, the ready-to-use data are of great importance.

\section{MODEL OF A SINGLE WIND TURBINE}

The behaviour of a single wind turbine (WT) at a particular location is modelled based on the wind data, turbine power curves, and some other factors, e.g. the availability time.

\subsection{Wind speed probability density}

The input for the WT model is Weibull's function of the in-situ wind speed probability density. However, defining this function is not an easy task, and the relevant data are not always available to a specialist performing the long-term planning who might know only the mean wind speed at the WF site. Development of the model involved analysis of the wind speeds at many locations in order to work out a set of Weibull's functions for different mean wind speeds [3, 4]. As an example, Fig. 1 shows the wind speed probability density measured at a WF location on North Harris Island (UK), with the mean speed of $8.4 \mathrm{~m} / \mathrm{s}$. The Weibull curve:

$$
f(x, \alpha, \beta)=\frac{\alpha}{\beta^{\alpha}} \cdot x^{\alpha-1} \cdot e^{-\left(\frac{x}{\beta}\right)^{\alpha}}
$$

was plotted for the parameters: $\alpha=1.85, \beta=9.48$, and fitted to the measured density.

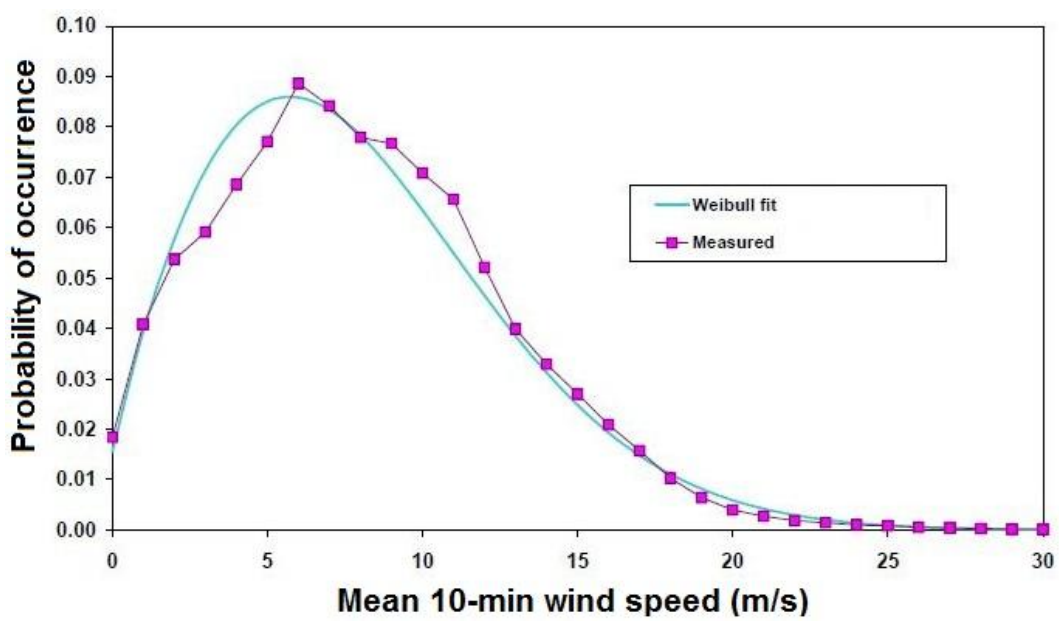

Fig. 1. Measured wind speed probability density and the best-fit Weibull function.

In the same way, many other locations were examined with the aim to work out the ready-to-use Weibull's functions for the mean annual wind speeds from 5.5 to $10 \mathrm{~m} / \mathrm{s}$. The wind speed distribution can differ even for equal mean wind speeds; 
therefore, priorities were given to unremarkable locations with average distributions. The total number of examined locations is 30 (a future extension is also possible).

\subsection{Power curve}

The next key parameter for a WF model is power curves of turbines. Usually, these curves are constructed within the limits of a single model, although separated models could be created if required. Power curves are easy to obtain from the wind turbine manufacturer, so the input data are available to the specialist performing calculation. At the same time, the model offers a whole set of power curves for the $500 \mathrm{~kW}, 1 \mathrm{MW}, 1.5 \mathrm{MW}$, and $2.5 \mathrm{MW}$ generators. As an example, Fig. 2 shows the power curve for a $500 \mathrm{~kW}$ wind turbine.

Power curves given by the WT manufacturer are usually plotted based on measured values. Otherwise, such a curve is to be derived from the wind potential using complicated equations, which often give imprecise result.

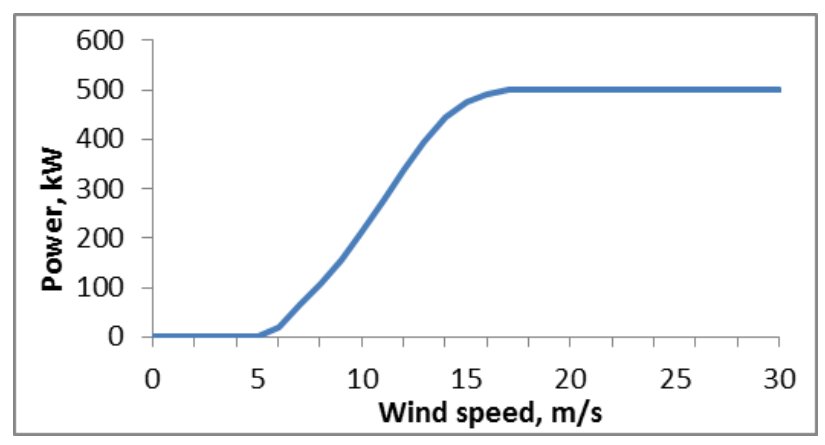

Fig. 2. The power curve of a $500 \mathrm{~kW}$ wind turbine.

Using special software, from each curve the relevant mathematical function is then extracted [5]. The whole curve is difficult to describe, so from zero to the cut-in wind speed the power is constant (i.e. zero), while above the rated values we have a constant rated power. However, the curve shape between the cut-in and the rated wind speeds can be accurately described by a polynomial function. The order of the function is recommended to be $\geq 5$. If this order is $<5$, the accuracy will most likely be below $95 \%$.

For the example shown in Fig. 2 the function is:

$$
P=0.0105 x^{5}-0.61502 x^{4}+13.4014 x^{3}-135.5567 x^{2}+685.7975 x-1,392.4221
$$

where $P$ is power, $\mathrm{kW}$;

$x$ is the wind speed, $\mathrm{m} / \mathrm{s}$.

In this case the function has a high accuracy (up to 99\%); however, it covers only a section of the curve from the cut-in wind speed to the rated. The power below the cut-in section is zero, and from the rated to the cut-out wind speed this is considered equal to the rated.

The power curve representation as a function simplifies further calculations, as, at this stage there are two ready-to-use functions: the wind speed probability 
density at the WT site and the power function. Multiplication of these curves gives the WT power probability density function, showing how often the turbine will generate at each power level.

This type of curve would be appropriate in financial calculations for a single turbine, making it easy to predict the annual energy production, the monetary profit and the payback period. However, this is not applicable to long-term planning tasks, since it is important to observe all PS elements operating in a single timescale in the cases when the WT power probability density function does not allow correction of the power value with time.

\subsection{Curve creation algorithm}

Since there is no appropriate function to describe accurately the wind speed distribution in time and no methods exist for long-term forecasting of wind speeds, for particular time and location in the future the wind speed is considered random in definite boundaries of values [6].

The proposed method for modelling the production curves of a wind power plant (WPP) uses a function that gives random values with the following limitations:

$>$ The lower limit of power values is zero.

$>$ The upper limit of power values is the maximum capacity of a WPP.

$>$ The function under consideration is that of WT power probability density.

Seasonal correction. Apart from the above limitations, the time-power (production) curve should be modelled with account for inconstancy of the power probability density through a year, e.g. the wind speed variations from month to month can be significant. Table 1 shows the mean wind speed distribution through a year for the same location (the UK data). In the model it is assumed that the deviation is up to $+/-25 \%$ for different months. In this example the maximum deviation from the mean value $(8.4 \mathrm{~m} / \mathrm{s})$ is observed in June and January.

Mean wind speed distribution through a year

\begin{tabular}{|c|c|}
\hline Month & $\begin{array}{c}\text { Mean wind } \\
\text { speed, } \mathbf{~} / \mathbf{s}\end{array}$ \\
\hline Jan & 10.7 \\
\hline Feb & 9.4 \\
\hline Mar & 9.1 \\
\hline Apr & 7.7 \\
\hline May & 7.2 \\
\hline Jun & 6.4 \\
\hline Jul & 6.5 \\
\hline Aug & 6.8 \\
\hline Sep & 8.6 \\
\hline Oct & 9.1 \\
\hline Nov & 9.7 \\
\hline Dec & 9.7 \\
\hline
\end{tabular}


Availability. The technical availability of turbines in the model is assumed to be 0.90 , which corresponds to the real turbine lifecycle and is adopted in practice.

Algorithm. The algorithm for modelling the curve of power production by a single wind turbine is presented in Fig. 3.

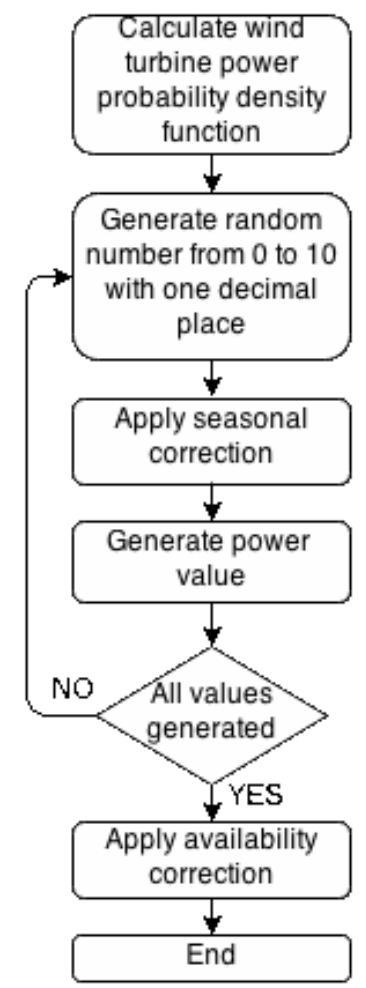

Fig. 3. The algorithm for creation of a time-power production curve.

According to the algorithm, the first step is to calculate the WT power probability density function. The generation of a random number from 0 to 10 is done to define the category to which the WT capacity will belong (the 0-10 range of numbers is associated with the most probable power value). Further, the random capacity value is found from one of the constant values equal to the power corresponding to the wind speeds from 0 to $30 \mathrm{~m} / \mathrm{s}$. Normally, the curve is built of 30 different repeating power values. The total number of values to be found is discussed below.

Level of detail (LOD). To reduce the calculation time and simplify calculations, the time-power (production) curve should have as small as possible number of values. At the same time, the number of observed values affects the LOD of a curve; besides, it should meet the requirements of a particular task. For example, to calculate the next-day energy market operation or to solve similar tasks it would be reasonable to observe the hourly or even minute curves, though in long-term planning there is no need for such a high LOD - the task is not to observe a single short-term operational state but to proceed up to the next 30 years 
and obtain the accurate final results based on forecasts, assumptions, approximations, and corrections.

The main requirements of any power plant modelling in long-term planning tasks are:

1. The production curve should include the maximum and the minimum (not the averaged) values.

It is important, since the production of a power plant can affect the production of other power plants: larger plants adapt to a wind power plant's production.

2. The curve should be time-scaled (with different power values realistically scattered along it).

There is a wide variety of possible combinations due to a large number of elements: wind power plants, hydro power plants, CHP plants, load, etc., each having its own unique characteristics. In order to make correct calculations, as many as possible combinations are to be considered.

3. The modelled production curve should result in the amount of energy similar to the given by the pattern curve, though differing from year to year.

In order to model a real situation, the energy production should not be taken equal every year; at the same time, large differences are not acceptable unless the power plant or load parameters are going to change significantly.

To find a balance between the calculation time (which can be reduced by minimizing the number of values) and the LOD of a curve (which should be as high as possible) is rather a complicated task. This paper investigates a scenario with 120 points on the WPP production curve. This means that there are 10 values for each of the 12 months of a year. Experimentally, after construction of multiple curves it has been defined that 10 values per month give a simple curve that meets the above requirements. Since the PS planning is based on the informational uncertainty and there is no reliable example for comparison, it is difficult to link the accuracy of final results to the LOD of WPP production curves.

\section{UNIFIED MODEL OF MULTIPLE WIND TURBINES}

Even if a wind farm possesses identical wind turbines, it would be incorrect to multiply a single turbine's production curve by the number of turbines, as the wind speed at a particular time can vary significantly throughout the farm [7].

On the other hand, it is impractical to create an individual model for each wind turbine, as the requirement for LOD is not so high in the PS planning tasks. The proposed approach to the creation of a unified model of multiple wind turbines relies upon our attempts to combine the complexity of considering the real behaviour of multiple wind turbines and the simplicity of having only one unified model.

\subsection{Wind farm landscape}

Wind speed variations throughout a farm can be explained by the landscape features of the occupied area. Normally, the farms located on flat terrain or the 
offshore farms have smaller deviations of wind speeds from turbine to turbine, while in the cases of hilly terrain these speeds can differ significantly.

Figure 4 illustrates such difference for two turbines that are close enough to each other. The hill in this case is an obstacle for the airflow directed to Turbine 2, while the way to Turbine 1 is fully open.

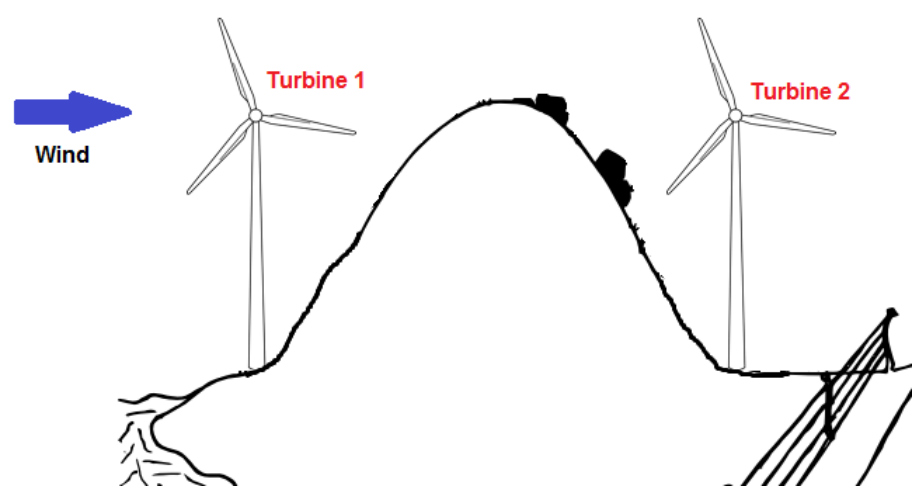

Fig. 4. Influence of the landscape on the wind speed.

Normally, in the case of wind direction shown in Fig. 4, the anemometer at Turbine 1 gives a much higher wind speed value than that at Turbine 2. With the wind direction changing by $180^{\circ}$, the situation becomes opposite: the wind speed at Turbine 2 would be much higher than at the Turbine 1 site.

In order to define possible wind speed variations at a single wind farm, a particular farm of the type was chosen. The farm is located in Oceania, has 97 turbines with the total capacity of $48.5 \mathrm{MW}$ (the maximum power of a single turbine being $500 \mathrm{~kW}$ ). Figure 5 shows a SCADA screenshot of this farm. Each cell represents one wind turbine and shows the power production at a particular time moment.

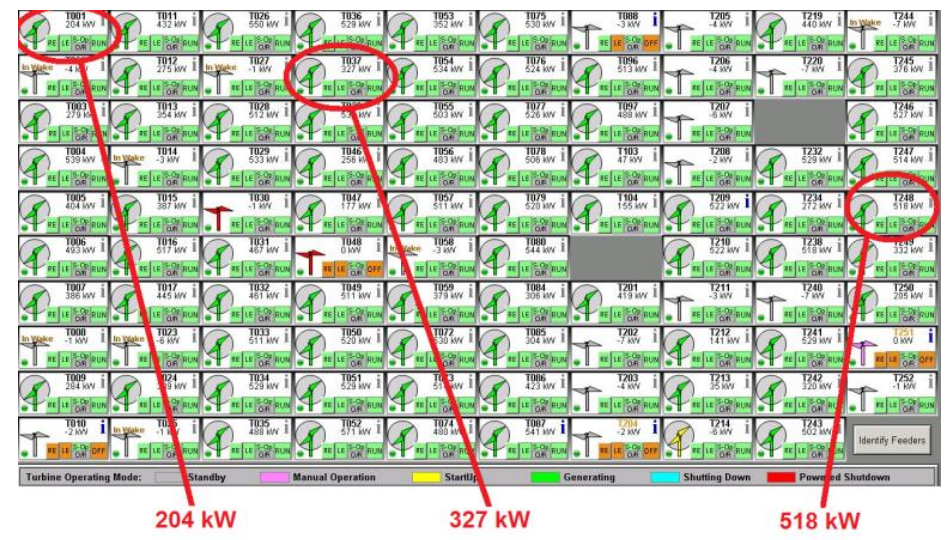

Fig. 5. SCADA screenshot of the wind farm.

Observations and historical data have shown that the maximal difference of power production can be up to $65 \%$ (between minimum and maximum or $+/-30 \%$ 
from the average) for a particular number of turbines. Obviously, it should be lower in the cases of flat terrain and for the offshore wind farms.

The model offers three types of wind farm: onshore - hilly terrain, onshore flat terrain, and offshore farms. In the modelling, the deviations from the average power value are calculated as follows.

For a hilly terrain:

$$
\% \text { Deviation }=60 \cdot \frac{\text { Number of Turbines }}{200}
$$

For a flat terrain:

$$
\% \text { Deviation }=30 \cdot \frac{\text { Number of Turbines }}{200}
$$

For offshore:

$$
\% \text { Deviation }=20 \cdot \frac{\text { Number of Turbines }}{200}
$$

In the first case (hilly terrain, $~ 100$ turbines) the deviation from average is $+/-30 \%$ for a specific proportion of turbines. For example, if at a certain point the average power is $200 \mathrm{~kW}, 1 / 5$ of the turbines will have the power:

$$
200+(0.30 \cdot 200)=260 \mathrm{~kW},
$$

while for one third of them this power will be:

$200-(0.30 \cdot 200)=140 \mathrm{~kW}$.

Figure 6 exemplifies the power distribution throughout such a wind farm.

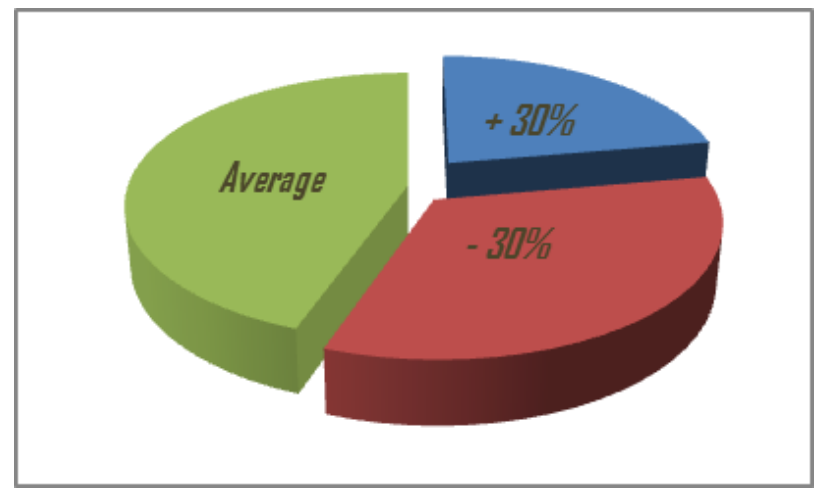

Fig. 6. Power distribution throughout a wind farm in the hilly terrain case.

The power values in this case are averaged for a current operational state and will be different for the next. Proportions of higher and lower power are changing with each new step (operational state), so there is a diversity of high/low total power combinations. As defined above, in the model 120 operational states (values on the production curve) per year are calculated in which the duration of one operational state is $8760 \mathrm{~h} / 120=73 \mathrm{~h}$.

Figure 7 presents a brief sketch of the proposed model. 


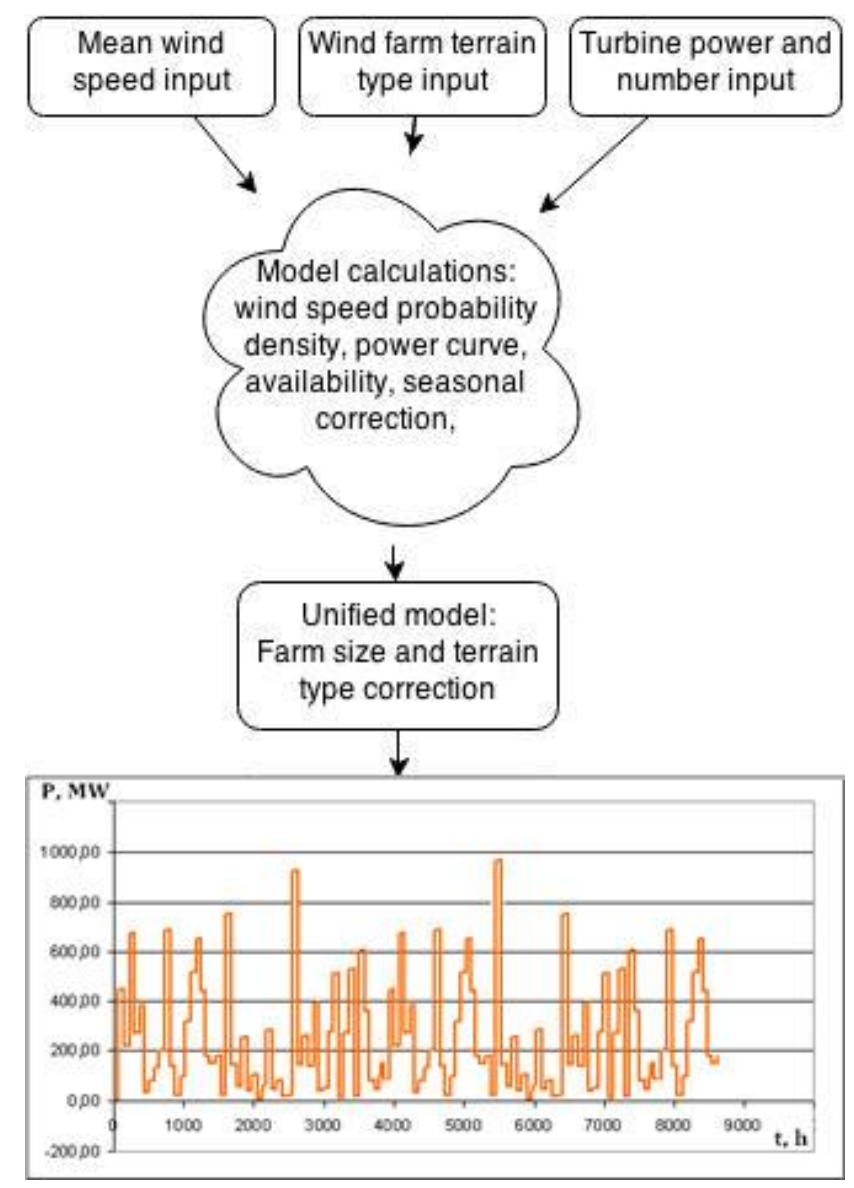

Fig. 7. Sketch of the proposed model

The curve in Fig. 7 allows the WPP modelling for up to 200 turbines; it shows a realistic energy production and meets all modelling requirements in longterm planning tasks.

\section{DISCUSSION AND CONCLUSIONS}

The results of our work have shown that by computer modelling it is possible to create an accurate model of large wind power plants. Since long-term planning might mean up to a 20 -year span, we tried to keep our model as simple as possible while not losing the required level of detail. The model has been proved to meet both requirements, thus providing the specialist with the ready-to-use curves and data.

So far, the algorithm for modelling the curve of power production by a single wind turbine with determination of the probability density of wind speed based on its mean values has not been sufficiently advanced, mainly due to a relatively small number of locations examined. In the near future, after thorough tests and corrections it is possible to apply the algorithm to the power system long-term planning and modelling software such as PSPlanner, which has been created at the Laboratory of Power System Mathematical Modelling and continues to develop, thus providing tools for the decision making in this area. 


\section{REFERENCES}

1. M. Buygi, G. Balzer, H. Shanechi, \& M. Shahidehpour (Nov. 2004). Market-based transmission expansion planning. IEEE Trans. on Power Syst., 19 (4).

2. Krishans, Z., Mutule, A., Merkuriev, Y., \& Oleinikova, I. (2011). Dynamic Management of Sustainable Development. Springer (Germany).

3. Nordpool spot market historical data. [Online]. Available: http://www.nordpoolspot.com/Market-data1/Downloads/Historical-Data-

Download1/Data-Download-Page/ [Accessed April 19, 2013]

4. U.S. Energy information administration, International Energy Statistics. [Online]. Available:

http://www.eia.gov/cfapps/ipdbproject/iedindex3.cfm?tid=6\&pid=37\&aid=12\&cid=reg ions\&syid=2001\&eyid=2010\&unit=BKWH/,[Accessed April 19, 2013]

5. Microsoft Excel instructions. [Online]. Available: http://office.microsoft.com/enus/excel-help/add-change-or-remove-a-trendline-in-a-chart-HP010007461.aspx

6. Shimamura, T., \& Yamashita, D. (March, 2013). Evaluation of smoothing effect of wind power generator aggregation on power system operation. Renewable Energy and Power Quality Journal, (11).

7. Barbounis, T.G., Theocharis, J.B., Alexiadis, M.C., \& Dokopoulos, P.S. (March, 2006). Long-term wind speed and power forecasting using local recurrent neural network models. IEEE Energy Conversion, 273 - 284.

\section{APKOPOTAIS VAIRĀKU VĒJA ĢENERATORU MODELIS}

O. Kočukovs, A. Mutule

Kopsavilkums

Rakstā ir apskatīta vēja elektrostaciju modelēšana ilgtermiņa attīstības plānošanas uzdevumos. Modelē̌sana tika veikta, izmantojot ierobežotu datu apjomu, kuri bija piejami lietotājam. Gatavie dati deva iespēju veikt ātru un precīzu modelēšanu. Raksts piedāva metodi kā pāriet no viena vēja ǵeneratora modeli uz vēja elektrostaciju (vairāki vēja ǵeneratori) modeli, kas atbilst ilgtermiņa attīstības plānošanas prasībām. Rakstā atspoguḷoti dati no Okeānijas un Lielbritānijas eksistējošām vēja elektrostacijām.

30.06.2014. 